\title{
Historia higieny woda pisana, red. Wojciech Ślusarczyk, Wyd. Quixi Media, Byd- goszcz 2017, ISBN 978-83-61840-41-1; http://wodociagi-polskie.pl/higiena.pdf
}

Czytanie książek nigdy nie stanowiło dla mnie problemu. Od czasu, kiedy jako dziecko udało mi się opanować tę wyjątkowa umiejętność, przez moje ręce przewinął się praktycznie każdy rodzaj literatury. Nie ukrywam jednak, że do omawianej pozycji podeszłam z nie małym dystansem. Książka o higienie, całkiem obszerna i w dodatku drobnym drukiem? Jednak zaskoczyła mnie; pisana prostym i zrozumiałym językiem okazała się być interesująca lektura.

Monografia została podzielona na sześć rozdziałów, z czego dwa rozbito na kilka podrozdziałów rozszerzających konkretne zagadnienia. Pomimo wspólnego mianownika, jakim jest czystość i higiena przez wieki, tematyka książki umiejętnie prowadzi czytelnika przez różne zagadnienia i pozwala spojrzeć mu na wiodąca problematykę $\mathrm{z}$ wielu perspektyw.

Pierwszy rozdział jest poprzedzony wstępem napisanym przez Wojciecha Ślusarczyka, który doskonale objaśnia, czego możemy spodziewać się po przeczytaniu lektury. Wstęp ten na pewno okaże się istotny dla wielu studentów, którzy przygotowuja 
prace związane z tematem wiodącym omawianej monografii, a także dla osób, które nie do końca wiedza, czego mogą oczekiwać biorąc do rąk tę lekturę.

Rozdział pierwszy napisany przez Adama Zemełkę nosi tytuł „Filozofia czystości”. Miło, kiedy ksiazżka zaskakuje czytelnika już przy pierwszej stronie. Tekst skupia się głównie na kulturze antycznej, ale nie tylko objaśniając sprawy przyziemne związane z czystością ciała. Skupia się również na drugim, metafizycznym wymiarze czystości, mianowicie czystości moralnej i czystości sumienia. Natrafiamy tu, na przykład, na bardzo ciekawy fragment o praktykowanych przez wieki rytuałach oczyszczenia z grzechu; czyż dzieci w Kościele Katolickim nie chrzcimy do dzisiaj? Z rozdziału tego dowiemy się także, że to Hiszpania wiodła prym w czystości w pierwszych stuleciach naszej ery, w dodatku nie przez obyczaje rdzennej ludności, ale dzięki mieszkającym tam Arabom.

„Dzieje wodociagów i kanalizacji”, a więc rozdział drugi pióra Krystyny Sokulskiej, nie był może tą częścia, która by mnie do reszty zafascynowała. Jednak praca autorki włożona w rozsądne zebranie najważniejszych informacji i przełożenie ich na zrozumiały, współczesny język jest godna podziwu. Tekst przedstawia kilka ciekawych wiadomości o tym, jak się żyło, kiedy o wodę było znacznie trudniej niż dzisiaj. I tak rozdział prowadzi nas od akweduktów do studni i tłumaczy kto, gdzie i kiedy miał najlepszy pomysł, żeby zapewnić sobie czystą wodę możliwie jak najbliżej progu własnych drzwi. $Z$ istnienia czegoś takiego, jak systemy grawitacyjne oczywiście nie zdawałam sobie sprawy. Autorka opowiada o tym, jak sytuacja zmieniała się przez wieki, jak rury wodociagowe przekształcały się z drewnianych na metalowe, a ludzie dochodzili do wniosku, że studnie czy wieże ciśnień można budować w taki sposób, żeby zaczęły cieszyć oko. Dalsze paragrafy opowiadają o tym, jak w obliczu zagrożenia chorobami zakaźnymi (m.in. dżuma) zaczęto szukać nowych sposobów na zaopatrzenie się w czystą wodę pitną i odprowadzanie nieczystości. Historia szamba przypuszczalnie nie utkwiłaby mi w pamięci, gdyby nie fakt, że w dawnych "latrynach" Pompejów archeologowie odnaleźli resztki mięsa żyrafy! Ostatnie zagadnienie poruszane przez autorkę przedstawia boom technologiczny XX wieku i szczelne, ceglane systemy kanalizacyjne, które wraz z szybkim rozwojem technologii doprowadziły do powstania łazienki, jaką każdy z nas zna z własnego mieszkania.

Rozdział trzeci „Kroniki mycia i niemycia” również rozpoczyna się od przedstawienia poczatków cywilizacji. Przygotowany został przez osobnych autorów. Pierwszy podrozdział, poświęcony higienie $\mathrm{w}$ czasach starożytnych, został napisany przez Annę Tatarkiewicz. Drugi autorstwa Katarzyny Chmielewskiej, opowiada o czasach średniowiecza, trzeci, pióra Katarzyny Pękackiej-Falkowskiej, zajmuje się epoką nowożytną. Czwarty podrozdział autorstwa Dariusza Chyły skupia się na rozwijajacej się medycynie, a piaty, napisany przez Annę Popielarczyk-Pałęgę, przedstawia dzieje higieny od lat 20. XX wieku (II Rzeczpospolita) aż po poczatek XXI stulecia. Rozdział „Kroniki mycia i niemycia” kończy tekst Rafała Bilskiego, który omawia współczesne standardy higieny. Ta część książki jest bardzo dobrze przemyślana, gdyż każdy z autorów opowiada o zwyczajach związanych z higieną w konkretnej epoce. Dzięki temu czytelnik jest $\mathrm{w}$ stanie zauważyć zmiany zachodzące $\mathrm{w}$ tym zakresie na przestrzeni wieków. 
Zaskakujący w podrozdziale autorstwa Tatarkiewicz może być fakt, że dbałość o higienę w starożytności nie różniła się jakoś szczególnie od tej w naszych czasach. Egipcjanie myjący się kilka razy dziennie? To robi wrażenie. Samo przypuszczenie, że mogli używać dezodorantu, zbija z nóg. W trakcie lektury po raz pierwszy natrafiłam na wzmiankę o higienie najmłodszych $\mathrm{w}$ antyku - i bardzo dobrze, bo wydaje mi się, że nigdy wcześniej nie słyszałam o tym problemie. I tak, z tekstu poznańskiej badaczki dowiadujemy się o rytualnym znaczeniu pierwszej kapieli dziecka, o tym, jak dużą wagę przywiązywano do pielęgnacji jego delikatnej skóry, i o wanienkach wykonywanych z żółwich skorup. Następnie autorka przechodzi od term do łazienek budowanych w prywatnych domostwach oraz od zwyczaju mycia się raz w tygodniu do codziennej kapieli i namaszczania ciała oliwą i olejkami. Zupełnie inaczej miały się, zgodnie $\mathrm{z}$ opinią Tatarkiewicz, sprawy związane $\mathrm{z}$ higieną $\mathrm{w}$ starożytnych Indiach, gdzie sama kapiel była swego rodzaju rytuałem, a poranne obmywanie się w rzece, częścią religii. Gdybym mogła wybrać czasy najbardziej imponujace mi zwyczajami higienicznymi, na pewno padłoby na Indie. Codzienne masaże? Złote baseny? Przypuszczalnie było tam dużo ciekawiej niż w niejednym dzisiejszym spa. Używane przez starożytnych Hindusów miód, mleko czy oliwa wpisałyby się znakomicie w dzisiejszą modę na kosmetyki naturalne.

Kolejny podrozdział, tym razem pióra Katarzyny Chmielewskiej, w pełni rozjaśnia "mroki średniowiecza”. Nigdy bym tej epoki nie podejrzewała o istnienie łaźni czy dbałość w higienie jamy ustnej. Pora na renesans, barok i oświecenie. Zgodnie z opinią Katarzyny Pękackiej-Falkowskiej z myciem nie było wtedy najlepiej, ale za to niezwykle rozwinął się przemysł perfumeryjny. Panowała zasada raczej maskowania wszelkiego brudu niż zmywania go z siebie woda. Zresztą nie przywiązywano wówczas szczególnej wagi do higieny, ważne żeby koszula była śnieżnobiała, inaczej człowiek mógłby się rozchorować od unoszącego się w powietrzu kurzu albo miazmatów. Bardzo ciekawą dermatozę - kołtun polski - także omówiono w tym rozdziale. Włosy niekoniecznie pielęgnowane, zlepiały się ze sobą tworząc ciężki splot. Nie jest to coś, z czym spotykalibyśmy się na co dzień w dzisiejszej Europie. I naprawdę nie miałam pojęcia, że menstruacja była w XVI-XVIII wieku aż tak dużym problemem. Nie jest to może czas, w którym kobiety czują się komfortowo, ale żeby od razu uważać je za przeklęte albo przynoszące nieszczęście i roztaczające wokół siebie furię?

Następny podrozdział wyprowadza nas z tych mrocznych wieków niemycia i zapoznaje z przełomem, jakim stało się uznanie higieny za dziedzinę medycyny. Od tego czasu mogło być już tylko lepiej. Hydroterapia czy antyseptyka bezsprzecznie poprawiły nie tylko stan zdrowia człowieka, ale i jego wygodę. No i prysznic, osobiście jestem zwolenniczką kapieli w wannie, acz, przyznaję, to musiał być przełom na skalę światowa! Omawiany przez Chyłę XIX wiek, to także wojny, które przyniosły ze sobą nowe odkrycia w dziedzinie medycyny, czas badaczy i naukowców. Autor przypomina postać Ludwika Pasteura i odkrycie przez niego bakterii. Zawsze jestem pod wrażeniem tego, że tyle wieków zajęło ludzkości połączenie brudu z chorobą i czuję wyjątkowy szacunek do naukowców, którym udało się przekonać społeczeństwo, że coś, czego nie widać, nie słychać i za bardzo nie da się zbadać, powoduje infekcje. 
Kolejna autorka, Popielarczyk-Pałęga, skupia się na sytuacji w dwudziestowiecznej Polsce i dobrze, bo pisze o tym całkiem ciekawie. Początkowo trudna sytuacja finansowa kraju po odzyskaniu niepodległości nie sprzyjała szerzeniu się zasad higieny, ale z czasem stopniowo się poprawiała. Okres PRL-u, który znam tylko z opowieści rodziców czy dziadków, a który omówiła Izabela Wodzińska, zilustrowano wieloma naprawdę ciekawymi zdjęciami. Pojawiaja się tu informacje o rodzimych markach kosmetycznych i sposobach propagowanie zdrowego stylu życia.

Rozdział trzeci kończy się opisem współczesnych zasad higieny, które niekoniecznie przyniosły nam wyłącznie korzyści. Bardzo ciekawie omówione przez Bilskiego normy higieniczne występujące we współczesnym społeczeństwie, rozwijająca się technika i nauka, ale też nadmierna sterylność przyczyniająca się do mutacji wśród drobnoustrojów, to główne zagadnienia ostatniej części książki.

W czwartym rozdziale zatytułowanym „Prywatna przyjemność czy społeczny obowiązek? Dzieje kapieli", napisanym przez Dariusza Chyłę, skupiono się szczegółowo na czynności, jaką było przez wieki branie kąpieli. W zasadzie książka tutaj trochę się powtarza, znowu omawiając zwyczaje starożytnych Greków, Rzymian, potem czasy chrześcijaństwa. W każdym z tych przypadków podkreślana jest rola łaźni jako nie tylko miejsca oczyszczania ciała, ale też spotkań towarzyskich. Potem autor pisze trochę o kulturze żydowskiej oraz o budowie i zwyczajach panujących wewnątrz osobliwych budynków kapielowych. Niestety, choć Chyła pisał bardzo ciekawie, a jego narrację uzupełniały fotografie, ryciny czy obrazy, których nigdy wcześniej nie widziałam, to poruszany przez niego temat trochę się zazębił z problemami omawianymi w rozdziale trzecim i nie czytało się go już z taką lekkością, jak wcześniejszych części książki. W kolejnych paragrafach Chyła omawiał łaźnie w Polsce, kapieliska i uzdrowiska. Potem przedstawił różnicę między łazienkami wczoraj i dzisiaj. Czułam się trochę, jakbym czytała historię hydrauliki, ale rozumiem zamysł autora. Różnorodność przedstawianych przez niego łazienek była ogromna. Od takich w zwykłych mieszkaniach, po łazienkę „pałacowa” jako element statusu. Kolejne watki to wanny, prysznice i kto, co, jak i w czym brał kapiele. Nigdy nie sądziłam, że o łazienkach można napisać aż tyle. Na pewno rozdział czwarty będzie interesujący dla osób z zamiłowaniem do architektury albo dekoracji wnętrz.

Rozdział piąty, „,Kulturowa historia defekacji”, został napisany przez Andrzeja Wypustkę. Cóż, brzmiało zagadkowo, bo co też można o tym napisać. Otóż, jak się okazało, można napisać nawet całkiem sporo! Autor rozpoczyna od samego powstania toalety. Oczywiście potrzeba stworzenia tego wynalazku pojawiła się dopiero wtedy, kiedy człowiek przestał prowadzić koczowniczy tryb życia i zaczał zakładać osady. Szczegółową historię akweduktów i wodociagów szczęśliwie mamy już za soba, więc nie będę się nad tym specjalnie pochylać. I tak, na początku Wypustek przedstawia toalety jako miejsca kompletnie nieustronne. Toalety wieloosobowe czy też zwyczajne załatwianie własnych potrzeb, tam gdzie się stało, jest z dzisiejszego punktu widzenia bardzo trudne do wyobrażenia. Szczególnie jeśli dodamy do tego obrazka komnaty ociekającego złotem Wersalu. Potem, jak zaznacza autor, zaczęto stawiać bardziej wymyślne konstrukcje. Tak od dziury w ziemi przeszliśmy do sedesu. Nie zdawałam też sobie sprawy z bardzo dużej popularności nocników w minionych wiekach. Oraz 
z tego, że powstanie spłuczki stanowiło rewolucję. A jednak wprowadzenie jej do powszechnego użytku nie było proste. Wymagało instalacji specjalnych mechanizmów czy choćby stworzenia odpływu dla nieczystości. Z biegiem czasu toalety, a raczej sedesy zaczęły przybierać najbardziej wymyślne kształty ograniczone jedynie przez ludzką fantazję. A jeśli już o fantazji mówimy, ilość materiałów wykorzystywanych w charakterze papieru toaletowego, no cóż... Wypustek przedstawia wyjątkowy przekrój od mchu, paprotek, patyczków, muszli, kamieni, wodorostów, tkanin aż w końcu papieru. Nie spodziewałam się, że jest to temat tak obszerny, ale jak autor zgrabnie podsumowuje: "defekacja i mikcja są demokratyczne” i dotyczą w równym stopniu nas wszystkich.

Rozdział szósty „Dzieje prania i sprzątania”, który zamyka książkę, został napisany przez Annę Popielarczyk-Pałęgę. Był to temat, którego się nie spodziewałam, stąd tekst autorki stał się dla mnie dużym pozytywnym zaskoczeniem. Doskonale dowodzi on unikatowości książki, która jest nie tylko zbiorem suchych faktów na temat higieny, ale też skupia się na nieoczywistych jej aspektach. Nigdy wcześniej nie trafiłam nawet na artykuł o podobnej tematyce. Autorka rozpoczyna od ukazania sprzątania w starożytności (chociaż śmiało możemy przypuszczać, że nawet człowiek pierwotny od czasu do czasu zamiatał swoją jaskinię) i prowadzi nas dalej w głąb tajników chemii gospodarczej. Zwraca również uwagę na społeczny i techniczny aspekt sprzątania, czyli kto sprzątał oraz jak rozwijała się technologia, żeby mu to sprzątanie ułatwić.

Książka zakończona jest swego rodzaju dodatkiem „Liderzy w branży”, przedstawiającym obecną sytuację wodociagów w Polsce. Jest to raczej dodatek branżowy aczkolwiek ciekawie przedstawia zasady funkcjonowania otaczającej nas miejskiej infrastruktury. Bardzo zgrabnie podsumowane informacje pozwalaja nawet niezorientowanemu $\mathrm{w}$ temacie czytelnikowi zrozumieć skomplikowane procesy dostarczania i oczyszczania wody w jego własnym domu i mieście.

Reasumujacc, książka niewatpliwie nie zalicza się do takich, które czyta się „ciężko". Na każdej stronie widać zaangażowanie autorów, i dotyczy to zarówno liczby przedstawionych przez nich informacji, jak wyraźnej próbie zainteresowania zwykłego śmiertelnika poruszaną tematyką. Bardzo rozsądnie podzielone rozdziały prowadziły mnie chronologicznie poprzez wieki, przez co dużo łatwiej było mi zrozumieć zależności i zmiany w podejściu do higieny różnych cywilizacji. Wtrącone ciekawostki, dzięki którym książka, mająca przecież charakter publikacji naukowej, stawała się lekka i momentami nawet zabawna, sprawiały, że chętnie rozpoczynałam lekturę kolejnych rozdziałów. Tematyka samej higieny została w omawianej monografii wyczerpana niemal do ostatniej kropli. Nie oznacza to jednak, że czytelnik zostaje nowa wiedza przytłoczon, choć momentami wkradały się w treści pewne powtórzone informacje.

Historia higieny woda pisana zasługuje na uwagę także ze względu na bogata szatę graficzną. Kilkaset kolorowych zdjęć, rycin i reprodukcji różnych obrazów, zarówno tych najbardziej istotnych z punktu widzenia danej epoki, jak i nam współczesnych, zostało bardzo starannie dobranych i nawet w dobie Internetu, kiedy wszystko możemy obejrzeć na ekranie naszych komputerów, przykuwało uwagę swoją unika- 
towością. Największe wrażenie wywołuje jednak interdyscyplinarność podejścia autorów, którzy napisali poszczególne rozdziały, i to, jak zgrabnie udało im się połączyć rożne dziedziny nauki. Medycyna, filozofia, historia, a nawet architektura. Wszystko to sprawia, że omawianą monografię może przeczytać każdy: zarówno laik mający pierwszy raz styczność z poruszanym w niej tematem, jak i studenci kierunków okołomedycznych i nauk społecznych, osoby związane z branżą kosmetyczną lub kanalizacyjna, ale też pasjonaci historii chcący pogłębić swoją wiedzę o wiele zaskakujących faktów. Uważam, że twórcy monografii chcieli stworzyć lekturę, która z powodzeniem może przeczytać każdy i wynieść z niej coś dla siebie. Czy udało im się zrealizować to zamierzenie? Moim zdaniem, zdecydowanie tak.

Natalia Grodzka 